$\left.\begin{array}{l}\text { Sournals } \\ \text { INTERNATIONAL JOURNAL OF } \\ \text { ORGANIZATIONAL LEADERSHIP }\end{array}\right) \begin{gathered}\text { INDUSTRIAL } \\ \text { MANAGEMENT } \\ \text { INSTITUTE }\end{gathered}$

\title{
Leader Member Exchange as a Mediator of the Relationship between Servant Leadership and Job Satisfaction: A Research on Turkish ICT Companies
}

\author{
Buket Akdol*, F. Sebnem Arikboga \\ Istanbul University, Faculty of Economics
}

\begin{abstract}
Keywords:

Leader Member

Exchange, Job

Satisfaction, Information and Communication

Technology Companies, ICT sector, Turkey

Received

11 April 2017

Received in revised form 20 November 2017

Accepted

29 December 2017

Correspondence:

buketakdol@gmail.com

Servant leadership (SL) is a theoretical framework that defines a leader's primary motivation and role as service to others. It introduces a holistic approach to work, advocates a sense of community, and promotes the sharing of power in decision making by showing humility, authenticity, and stewardship. Servant leader also develops and empowers employees by standing back, encouraging to be autonomous, and by forgiving mistakes. On the other hand, the Leader Member Exchange (LMX) Theory explores the one-on-one relationship between a leader and the individual follower independently, instead of focusing on the general relationship between the leader and the group as a whole. The objective of this study is to test the effect of SL on job satisfaction (JS) in Turkish business context and to identify the mediator effects of LMX on the relationship between SL and JS by quantitative data obtained from Information and Communication Technologies (ICT) Sector companies in Turkey. The multidimensional leadership measure developed by Van Dierendonck and Nuijten (2011), four-dimension LMX Measure of Liden and Maslyn (1998), and short form of Minnesota Job Satisfaction Questionnaire (MSQ) developed by Weiss, Dawis, England, and Lofquist (1967) were used as assessment tools on questionnaire. Research results show that there is a partial mediator effect of LMX on the relationship between SL and JS.
\end{abstract}

The demographic, social, and technological changes of last decades of $20^{\text {th }}$ century transformed the traditional organizations of 1900s. Over time, innovation and customer satisfaction became at least as important as the standardization and efficiency of processes. Moreover, the organizations have consisted of more diverse employees of different gender, ethnicity, religions, nationality, and age groups. One can also extend this discussion to the intellectual 
capital driven organizations of the new millennium. For these companies the needs of the employee have direct impact on the output of the organization.

It is no surprise that the role of leadership in engaging employees and driving innovative organizations have become a popular area of research in the last decade (Luthans, 2002; Garcia-Morales, Llorens-Montes, \& Verdu-Jover, 2008a, b). There has also been a growing need for people-oriented leadership styles that put the interests of the employees and ethical concerns above securing short-term success and corporate profits. The theory of SL offers insight into this leadership paradigm that increases emphasis on service to others, building a sense of community within the organization, power sharing, and collaborative decisionmaking. Servant leaders can affect JS by focusing on the needs of followers, developing their potential, and empowering them. The current study focuses on mediating the role of LMX on the relationship between SL and JS.

\section{The Literature Review}

\section{Understanding The Concept of SL}

Greenleaf developed the idea of "servant as leader" during his long career at large US organizations. He first used the term, the servant leader, in 1970. The main argument of Greenleaf is that true leadership become apparent from those whose main motivation is an extreme desire to be of benefit to others and the great leader is first experienced as a servant to others and this basic fact is of the greatest importance to his or her greatness.

Following Greenleaf, Spears (1995) and many others worked on explaining Greenleaf's ideas and building a theoretical framework for the SL concept. Spears defined ten characteristics of the servant leader as listening, empathy, healing, awareness, persuasion, conceptualization, foresight, stewardship, commitment, and building community. Laub (1999) defined the concepts of SL and servant organization. In addition to his conceptual work, he also developed a 60-item assessment tool -the Organizational Leadership Assessment (OLA)clustering the six dimensions of SL characteristics (personal development, valuing people, building community, displaying authenticity, providing leadership, and sharing leadership).Page and Wong (2000) built a conceptual SL model and identified four categories in their model that are character, relation, task, and process; following this, they also built a scale with 12 dimensions. Dennis and Winston (2003) reduced the number of dimensions in the scale to three, namely vision, empowerment, and service. On the other hand, Russell and Stone (2002) mentioned nine functional characteristics (vision, honesty, integrity, trust, service, modeling, pioneering, appreciation of others, and empowerment) and eleven additional characteristics of SL (communication, credibility, competence, stewardship, visibility, influence, persuasion, listening, encouragement, teaching, and delegation). Patterson (2003) also created a conceptual model including seven dimensions, namely agapao love, humility, altruism, vision, trust, empowerment, and service.

The SL concept has been considered in many different dimensions over many decades. A number of researchers developed assessment tools to define a commonly accepted concept of SL and to explore the applicability of the concept in the real world organizations. The conceptual framework of this study is based on a conceptual model formed by Van Dierendonck (2011). Our research framework suggests using the Multidimensional Measure 
developed by Van Dierendonck and Nuijten (2011). This measure was tested in United Kingdom, Netherlands (Van Dierendonck, 2011), and in Turkey. Based on these studies, the dimensions of the SL and the conceptual framework of this research will be discussed below.

In the dimension of empowerment, servant leader encourages the followers to use their talents and to come up with new ideas, gives them the authority to make decisions, helps them to solve problems on their own instead of prescribing solutions, offers opportunities to learn new skills, and helps the followers to develop themselves.

Accountability is about holding individuals or teams responsible for the work they carry out, for the outcomes that are under their control, and for the specific ways they handle tasks.

Standing back is about a leader who keeps himself/herself in the background while giving credit to others, without chasing for recognition or rewards for the things he/she does for others.

Humility in leadership starts with the acceptance of the fact that everybody can be wrong and can make mistakes. Servant leaders acknowledge their limitations and ask for help of others to overcome those limitations. Humility is about the leader's ability to admit his/her own mistakes and shortcomings and to accept criticism with the intention to learn from it.

Authenticity is about self-expression, and accurately representing leader's intentions and feelings regardless of the professional roles.

Courage is about a leader's willingness to take risks to bring solutions consistent with his/her own values and convictions, even in cases where there is uncertainty about upper management support. As a leader characteristic, courage differentiates the servant leader from others. Within the organizational context, courage is about challenging conventional models of working behaviors and drives innovation and creativity.

Forgiveness for a leader is about failing to remember what went wrong in the past, accepting others' mistakes, and remaining objective towards a follower even after an insulting behavior by the follower. The follower is more likely to feel accepted, worry less about making mistakes, and being rejected. The purpose of forgiveness for the servant leader is about helping the followers to achieve their best in what they do.

Stewardship is about considering the long-term vision despite the short-term pressures; holistic comprehension of the problems; caring about social responsibility, loyalty, and teamwork as well as the responsibility to the stakeholders of the organization.

In an attempt to better understand the concept of SL, we can compare it with other leadership paradigms. Researchers discuss traditional leadership styles such as autocratic leadership (Laub, 2003) or command leadership (Page\& Wong, 2000) as the antithesis of SL. However, this discussion on leadership styles go beyond traditional or SL. Laub (2003) recognizes that "most organizations today operate with a paternalistic view of leadership" and these organizations are neither autocratic or servant. Moreover, transformational leadership has been one of the most popular leadership styles in the fast cycled and highly competitive business environment where the organizations are expected to be creative and adaptive. Table 1 represents the comparison of leadership styles. 
Table 1

Comparison of Leadership Styles

\begin{tabular}{|c|c|c|c|c|}
\hline & Autocratic Leadership & $\begin{array}{l}\text { Paternalistic } \\
\text { Leadership }\end{array}$ & $\begin{array}{l}\text { Transformational } \\
\text { Leadership }\end{array}$ & $\begin{array}{l}\text { Servant } \\
\text { Leadership }\end{array}$ \\
\hline $\begin{array}{l}\text { Focus of } \\
\text { Leader }\end{array}$ & Tasks & Needs of Organization & $\begin{array}{l}\text { Organizational } \\
\text { Objectives }\end{array}$ & The Needs of Followers \\
\hline $\begin{array}{l}\text { Role of } \\
\text { Leader }\end{array}$ & $\begin{array}{l}\text { To Command Followers } \\
\text { to Fulfill the Tasks }\end{array}$ & $\begin{array}{l}\text { To Treat Followers as } \\
\text { Children }\end{array}$ & $\begin{array}{l}\text { To Inspire Followers to } \\
\text { Pursue Organizational } \\
\text { Goals }\end{array}$ & To Serve Followers \\
\hline $\begin{array}{l}\text { Role of } \\
\text { Follower }\end{array}$ & $\begin{array}{l}\text { Obey the Commands, } \\
\text { Orders, Rules and } \\
\text { Regulations }\end{array}$ & To be Obedient & $\begin{array}{l}\text { To Pursue } \\
\text { Organizational } \\
\text { Goal }\end{array}$ & $\begin{array}{l}\text { To Become Wiser, Freer, } \\
\text { More Autonomous }\end{array}$ \\
\hline $\begin{array}{l}\text { Expected } \\
\text { Outcomes }\end{array}$ & $\begin{array}{l}\text { Achievement of Tasks } \\
\text { and Objectives }\end{array}$ & $\begin{array}{l}\text { Loyalty and Commitment } \\
\text { to the Leader and } \\
\text { Organization }\end{array}$ & $\begin{array}{l}\text { Increased Effort, } \\
\text { Satisfaction and } \\
\text { Productivity; } \\
\text { Organizational Gains }\end{array}$ & $\begin{array}{l}\text { Follower Satisfaction, Development, } \\
\text { Empowerment; Commitment to } \\
\text { Service, Societal } \\
\text { Betterment }\end{array}$ \\
\hline
\end{tabular}

The paternalistic leader behaves like a parent and regards followers as his or her children. The paternalistic leader creates a close relationship between himself and his followers by guiding, protecting, and being concerned about the general well-being of the followers. Unlike the servant leader, the paternalistic leader focuses on the needs of the organization, not on the wishes or the needs of the followers. There is a sense of hierarchy with limited power sharing and the followers are expected to be loyal and obedient. The paternalistic leader's benevolent and autocratic characteristics place his style right in the middle of autocratic and SL styles (Laub 2003; Oner, 2012). Most research conducted in Western societies on this topic discusses paternalism as an obstacle before SL. In contrast, in Eastern cultures such as Turkey, employees' perception of servant leader is similar to paternalistic leader. This is because of SL attributes as perceived by Turkish employees that reflect a higher degree of people orientation (Oner, 2012). According to GLOBE study, SL can occur in the cultures that are characterized by "humane orientation" and "low power distance" (House et al., 2004; Winston \& Ryan, 2008). There is a certain perception of SL attributes as being people oriented among Turkish employees (Oner, 2012). High power distance does not prevail in Eastern cultures neither, because of competitive business environment and the coexistence of different generations within the same organizations. This can explain the popularity of SL concepts in Eastern societies.

Developed by Burns (1978) and enhanced by Bass (1985, 1998), transformational leaders make followers enthusiastic to achieve more by focusing on the follower's beliefs and helping the follower align them with the values of the organization. Transformational leaders motivate their followers to attain better performance for the sake of the organizational purposes. Servant-leaders focus more on the interest of their followers (Patterson, 2003) and trust their followers to produce best outcomes for the sake of the organization while acting in their best interest (Stone, Russell, \& Patterson, 2004). Morality (Graham 1991), ethical concerns (Clegg, Kornberger, \& Rhodes, 2007), and social responsibility (Reinke 2004) are also used in the characterization of SL as a more people centered concept for leadership (Van Dierendonck \& Nuijten, 2011). 


\section{SL and LMX}

Developed by Graen (1995), LMX theory suggests that leaders do not take advantage of the same style in dealing with all subordinates, but rather create a distinct type of relationship or exchange with each subordinate (Liden \& Maslyn, 1998). High-quality (group-in) relationships are distinguished by high levels of trust, interaction, support, and formal - informal rewards. Leader has greater attention to follower's interests and follower benefit from this relationship. Low-quality relationships are characterized by a high task orientation and mistrust. Leaders give much less attention or benefits to followers in such relationships (Dansereau, Graen, \& Haga, 1975; Liden \& Maslyn, 1998). There are many tools with different number of dimensions and items to measure LMX. Liden and Maslyn (1998) offer a four-dimensional conceptualization model supported with empirical data. This model consists of the dimensions of affect (liking one another), loyalty (loyalty to each other), contribution (task-related behavior), and professional respect (based on reputation in line of work).

SL develops a high quality LMX by empathizing with followers, building interpersonal trust, and focusing on the developmental needs of the employees. Servant leaders develop strong supportive relationships with all followers. Also in high-LMX leaders develop trusting and mutually beneficial relationships with followers (Van Dierendonck, 2011).

Based on this argument, Wu et al. (2013) expected that SL to be positively correlated to LMX for three reasons: Followers trust servant leaders because servant leaders are perceived to be ethical, fully accept their followers, and empathize with them. By building interpersonal trust, servant leaders are likely to have high quality relationships with their followers; in addition, servant leaders empower followers and provide them with a good degree of accountability based on their abilities, needs, and what they can control in an outcome. As a consequence, followers enjoy greater autonomy and discretion on their jobs and are more likely to meet the requirements of their roles; moreover, as role models, servant leaders influence the followers' identity. In return, followers internalize the servant leader's values and beliefs, seek and gain praise and recognition from the leaders.

\section{The Effect of SL on JS and the Relationship with LMX}

The JS can be defined as the reaction of an employee against his or her occupation or organization. JS is an enjoyable or positive emotional state happening due to an appraisal of one's job or job experiences (Locke, 1976).

JS is associated with organizational variables such as organizational citizenship behavior, turnover, and absenteeism and is affected by organizational culture and leadership style. It also contributes to increased productivity and effectiveness. Organizational studies including empirical research at the organizational level have argued that leadership styles have effect on JS (Adler \& Reid, 2008; Bushra, Usman, \& Naveed, 2011; Choi \& Lee, 2011; Madlock, 2008). There are many studies examining the relationships between SL and JS. Most of these studies are doctoral dissertations that use correlational data and suggest positive correlation between SL style and JS among the employees across many lines of businesses (Amadeo, 2008; Cerit, 2009; Ding, Yu, Song, \& Lu, 2012; Herbert, 2003; Lolita Regina, 2008; Washington, 2007).

Statistical studies have shown that being a member of the in-group or in other words, having a high quality LMX relationship, is a rewarding and a desirable position within an 
organization. The leaders delegate more decisions to the members of the in-group and the ingroup members receive more rewards including higher JS (Epitropaki \&Martin, 2005; Gerstner \& Day, 1997; Ozutku, 2007).

\section{The Study}

The purpose of this research is to determine the effect of SL on JS, examine the relationship between SL and LMX, and measure the mediating role of high quality LMX between SL and JS. The research model is presented in Figure 1.

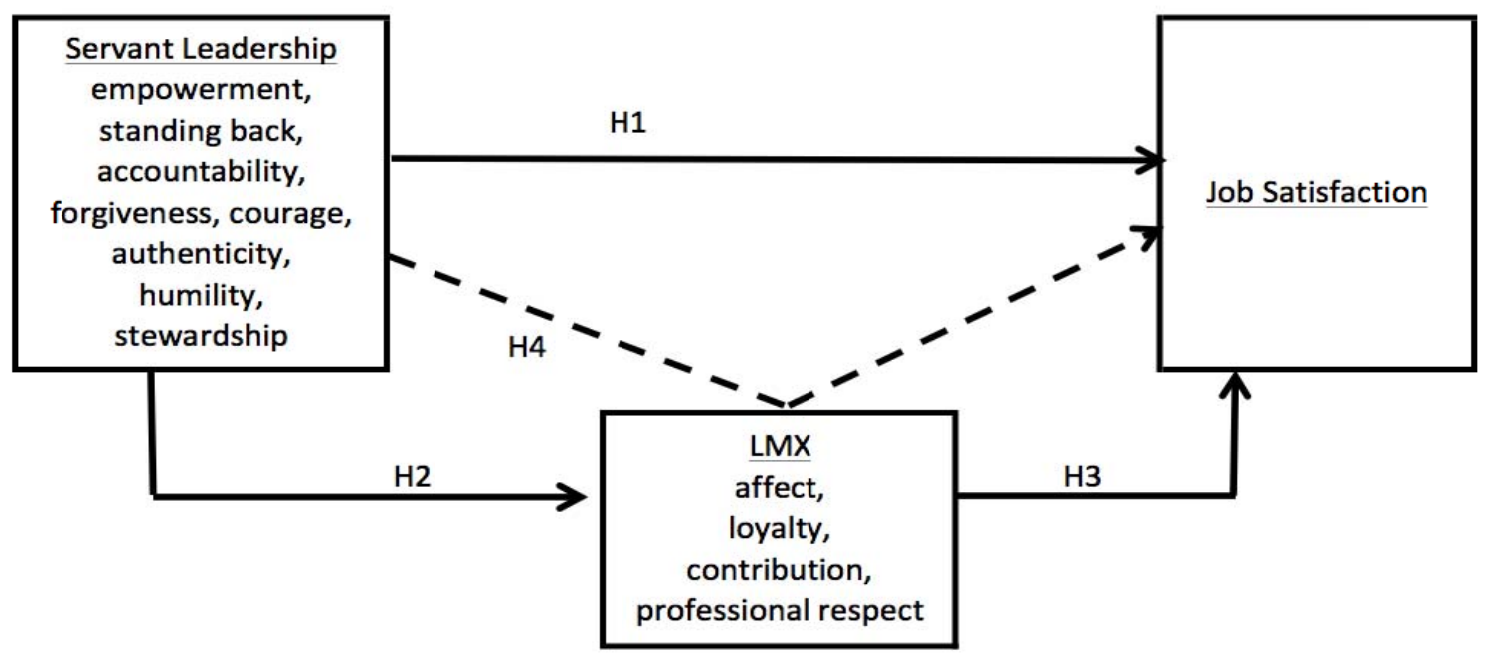

Figure 1. Research Model

The above model is created using a portion of the conceptual SL model of Van Dierendonck (2011). Above presented model implies an effect of SL on LMX and JS. LMX can be used as a framework to explain the attributes of the relationship between servant leader and followers. SL builds a high quality LMX between servant leader and the followers mostly through mutual trust and respect. Servant leader persuades the followers and builds consensus in the groups through the influence tactics of explanation, reasoning, factual evidence, inspirational appeals, and consultation. In addition, servant leader empowers and develops followers with the right mixture of providing autonomy and direction. These efforts all together help build a high quality LMX between the servant leader and the followers (Van Dierendonck, 2011)

\section{Research Questions and Research Hypotheses}

The main questions we aim to answer in this research framework are:

- Does SL have a positive effect on JS?

- Is there any positive correlation between SL and high quality LMX?

- Is there a mediating role of high quality LMX on SL and JS?

Based on the research questions, the following research hypotheses guided the present study:

$\mathbf{H}_{\mathbf{1}}$ : SL has significant and positive effect on overall JS.

$\mathbf{H}_{2}$ : SL has significant and positive effect on LMX.

$\mathbf{H}_{3}$ : LMX has significant and positive effect on overall JS.

$\mathbf{H}_{4}$ : LMX has a partial mediating role on the relationship of SL and JS. 
The purpose of this model is to explore the partial mediating role of high-quality LMX on the SL and JS. There can be other factors that affect the relationship between SL and JS. For example, Van Dierendonck mentioned about the psychological climate such as trust and fairness in his conceptual model which is the base of this study. Also Mayer, Bardes and Picollo (2008) showed that the organizational justice has a partial mediating role on the relationship between SL and JS.

\section{Method and Results}

The objective of the current study was to test the effect of SL on JS in Turkish business context and to identify the partial mediator effects of leader-member exchange on the relationship between SL and JS by quantitative data obtained from Information and Communication Sector companies in Turkey. A link of the online questionnaire was sent to the employees of The ICT500 Turkey List companies and a total of 628 completed questionnaires were received. Respondents were asked to rate their JS and immediate manager on a variety of leadership behaviors according to SL style and leader member exchange by 5 point Likert type scale.

The demographics of the respondent set showed that $\% 65$ of the respondents were male. Considering their age, $\% 52.6$ of the respondents were 18 to 29 years old, \% 43 between 30 to 44 years old, and \%4.4 was older than 44 . Following this, $\% 88$ of the respondents had a higher education degree, $\% 87$ of them had less than 6 years experiences in the same company, and $\% 75$ of the respondents had less than 3 years experiences in the same position.

The ICT500 Turkey List is a yearly-based research made by an independent institution called Interpromedya. The purpose of the research was to identify the subsectors and sizes of the ICT companies in Turkey. Regarding the sector, the respondent set in term of subsector and size showed $\% 43.2$ for software, $\% 2.9$ for hardware, $\% 29.8$ for telecommunication and service providers, $\% 8.3$ for system integrators, \%6.8 e-commerce companies, and $\% 9$ for other subsectors. Considering the size, $\% 61.3$ was large (more than 250 employees), $\% 14.8$ was medium (50 to 249 employees), and \%23.9 was small or micro (less than 50 employees).

The questionnaire used different assessment tools. The first one was a multidimensional leadership measure developed by Van Dierendonck and Nuijten in (2011). This assessment tool aims to measure SL style and contains eight different dimensions including empowerment, accountability, standing back, forgiveness, humility, authenticity, courage, and stewardship. Second assessment tool was four-dimensions LMX Measure of Liden and Maslyn (1998). Affect, loyalty, contribution, and professional respect are the dimensions of LMX. In order to measure overall JS, short form of Minnesota JS Questionnaire (MSQ) developed by Weiss et al. (1967) was used as assessment tool in the online questionnaire. There are twenty facet of JS in this assessment tool. Table 2 exhibits the reliabilities of scales.

Table 2

Reliabilities of Scales

\begin{tabular}{ccccc}
\hline Scale & Mean & N & N of Items & Cronbach's Alpha \\
\hline SL & 3.50 & 628 & 30 & 0.94 \\
LMX & 3.65 & 628 & 12 & 0.94 \\
Satisfaction & 3.12 & 628 & 20 & 0.94 \\
\hline
\end{tabular}


Reliability analyses were performed and the Cronbach's alpha was calculated for every variable. As it is shown in Table 2, the value of Cronbach's alpha is greater than 0.7 for every variable and acceptable according to Hairs, Anderson, Tatham, and Black (1998). To test the mediating effect of LMX on the relationship between SL and JS, a three-step regression analysis suggested by Baron and Kenny (1986) was used. In this research conditions that are expected for mediating effect are listed below according to Baron and Kenny's (1998) methodology:

- SL (independent variable) must have an effect on JS (dependent variable) and LMX (intermediary variable) $\left(\mathrm{H}_{1}\right.$ and $\left.\mathrm{H}_{2}\right)$;

- LMX (intermediary variable) must have an effect on JS (dependent variable) $\left(\mathrm{H}_{3}\right)$;

- When LMX (intermediary variable) is involved in the regression analysis together with SL (independent variable) LMX must have an effect on JS (dependent variable) as the regression coefficient of SL upon JS drops $\left(\mathrm{H}_{4}\right)$.

Table 3 shows the regression analysis result.

Table 3

Regression Analysis Result

\begin{tabular}{|c|c|c|c|c|c|c|c|c|c|}
\hline \multirow[b]{2}{*}{ IndependentVariable } & \multicolumn{5}{|c|}{ Coefficients } & \multicolumn{2}{|c|}{ Model Summary } & \multicolumn{2}{|c|}{ ANOVA } \\
\hline & B & StdError & Beta & $\mathrm{T}$ & $\mathrm{P}$ & $\mathrm{R}$ & $\mathrm{R}^{2}$ & $\mathrm{~F}$ & $\mathrm{P}$ \\
\hline \multicolumn{10}{|c|}{ 1. Step } \\
\hline SL & 0.77 & 0.03 & 0.64 & 21.19 & 0.00 & 0.64 & 0.41 & 449.21 & 0.00 \\
\hline \multicolumn{10}{|c|}{ DependentVariable: JobSatisfaction } \\
\hline \multicolumn{10}{|c|}{ 2. $\quad$ Step } \\
\hline SL & 1.09 & 0.02 & 0.84 & 38.96 & 0.00 & 0.84 & 0.70 & 1518.46 & 0.00 \\
\hline \multicolumn{10}{|c|}{ DependentVariable: LMX } \\
\hline \multicolumn{10}{|c|}{ 3. Step } \\
\hline SL & 0.43 & 0.06 & 0.36 & 6.70 & 0.00 & 0.67 & 0.45 & 255.39 & 0.00 \\
\hline LMX & 0.30 & 0.05 & 0.33 & 6.02 & 0.00 & & & & \\
\hline \multicolumn{10}{|c|}{ DependentVariable: JobSatisfaction } \\
\hline
\end{tabular}

Regarding the first step regression analyses, SL has a significant $(\mathrm{p}<0.05)$ and highly positive effect (Beta $>0.50$ ) on JS. On the second step, the result of regression analysis shows that SL has a significant and very highly positive effect (Beta $>0.70)$ on LMX. In the third step LMX is included to the analysis together with SL as dependent variable. Final regression analysis suggests that there is a significant and positive effect on JS. As the Beta value for SL is lower than first step analysis, one can claim that there is a partial mediator effect of LMX on the relationship between SL and JS. Partial mediation, where a direct relationship is present together with the mediated effect is found in this analysis. The Sobel test was also run for the mediator effect. To this end, test statistic for Sobel is 5.96 and the p value is 0.00 on 0.05 significance level. As the results present, all hypotheses of this research were supported. 


\section{Discussion and Conclusion}

The regression analyses suggest that there is a significant and positive effect of SL style and LMX on overall JS in Turkish Business context. Also a partial mediating role of LMX on the relationship between SL and JS was found in Turkey's ICT companies. According to the results, it is possible to claim that servant leaders can affect the positive job attitudes of employees by creating more in-group relationships with them.

SL is a relatively emerging field of management research, so it is important to discuss the existence and significance of the relationship between SL and JS. The goal of this study is to bring more clarity to the discussions about the relationship between SL and JS. One contribution of this study is its ability to demonstrate that servant leaders accomplish this through building high-quality relationships with their subordinates (LMX). This is of practical importance because highly competitive and creative businesses rely on high ratings of JS as a competitive advantage. On the other hand, the field of SL moves from being prescriptive to becoming descriptive. We hope this research will be evidence in the way to contribute the descriptive side of the field.

This study mainly focuses on overall JS, but the concept can be extended to consider the components (facet) for JS including the job itself, compensation, promotion, supervisors, and colleagues. Also sub dimensions of SL style were not considered separately in the analyses. It is possible to extend these analyses regarding the sub-dimensions. The contribution of this study is to start an academic discussion about the relationship between SL, LMX, and JS on the ICT companies in Turkey. The framework of this study could be used to expand the investigation into other cultures and industries in emerging economies.

\section{References}

Adler, R. W., \& Reid, J. (2008). The effects of leadership styles and budget participation on job satisfaction and job performance. Asia-Pacific Management Accounting Journal, 3(1), 21-46.

Amadeo, C. A. (2008). A correlational study of servant leadership and registered nurse job satisfaction in acute health care settings (Unpublished doctoral dissertation). School of Advanced Study, University of Phoenix.

Baron, R. M., \& Kenny, D. A. (1986). The moderator-mediator variable distinction in social psychological research: Conceptual, strategic, and statistical considerations. Journal of Personality \& Social Psychology, 5, 1173-1182.

Bass, B. M. (1985). Leadership and performance beyond expectations. New York: Free Press.

Bass, B. M. (1998). Transformational leadership: Industrial, military, and educational impact. Mahwah, NJ: Lawrence Erlbaum Associates.

Burns, J. M. (1978). Leadership. New York: Harper \& Row.

Bushra, F., Usman, A., \& Naveed, A. (2011). Effect of transformational leadership on employees' job satisfaction and organizational commitment in banking sector of Lahore (Pakistan). International Journal of Business \& Social Science, 2(18), 261-267.

Cerit, Y. (2009). The effects of servant leadership behaviours of school principals on teachers' job satisfaction. Educational Management Administration \& Leadership, 37(5), 600-623.

Choi, S. L., \& Lee, Y. T. (2011). Relationship between leadership style, job satisfaction, and employees' turnover intention: A literature review. Research Journal of Business Management, 5(3), 91-100.

Clegg, S. R., Kornberger M., \& Rhodes, C. (2007). Business ethics as practice. British Journal of Management, 18, $107-122$.

Dansereau, F., Graen, G. J., \& Haga, W. (1975). A vertical dyad linkage approach to leadership within formal organizations. Organizational Behavior \& Human Performance, 13, 46-78.

Dennis, R. S., \& Winston, B. E. (2003). A factor analysis of Page and Wong's servant leadership instrument. Leadership \& Organizational Development Journal, 24(8), 455-459. 
Ding, D., \& Yu, H., Song, Y., \& Lu, Q. (2012). Relationship of servant leadership and employee loyalty: The mediating role of employee satisfaction. Business, 4(3), 208-215.

Epitropaki, O., \& Martin R. (2005). From ideal to real: A longitudinal study of implicit leadership theories, leader-member exchanges and employee outcomes. Journal of Applied Psychology, 90(4), 659-676.

Garcia-Morales, V. J., Llorens-Montes, F. J., \& Verdu-Jover, A. J. (2008a). The effects of transformational leadership on organizational performance through knowledge and innovation. British Journal of Management, 19, 299-319.

Garcia-Morales, V. J., Matias Reche, F., \& Hurtado Torres, N. (2008b). Influence of transformational leadership on organizational innovation and performance depending on the level of organizational learning in the pharmaceutical sector. Journal of Organizational Change Management, 21(2), 188-212.

Gerstner, C. R., \& Day, D. V. (1997). Meta-analytic review of leader-member exchange theory: Correlates and construct issues. Journal of Applied Psychology, 82(6), 827-844.

Graham, J. W., (1991). Servant-leadership in organizations: Inspirational and moral. Leadership Quarterly, 2(2), $105-119$.

Graen, G. B., \& Uhl-Bien, M. (1995). Relationship-based approach to leadership: Development of Leader-Member Exchange (LMX) theory of leadership over 25 years: Applying a multi- level multi domain perspective. Leadership Quarterly, 6(2), 219-247.

Greenleaf, Roberts K. (1970). The servant as leader. Cambridge, Mass: Center for Applied Studies.

Hairs, J. F., Anderson, R. E., Tatham, R. L., \& Black, W. C. (1998). Multivariate data analysis (5 ${ }^{\text {th }}$ ed.). New Jersey, Upper Saddle River: Prentice Hall.

Hebert, S. C. (2003). The relationship of perceived servant leadership and job satisfaction from the follower's perspective (Unpublished doctoral dissertation). School of Business, Capella University.

House, R. J., Hanges, P. J., Javidan, M., Dorfman, P. W., \& Gupta, V. (2004). Culture, leadership and organization: The GLOBE study of 62 societies. Thousand Oaks: Sage Publication.

Lolita Regina, J. (2008). An exploratory study of servant leadership, emotional intelligence, and job satisfaction among hightech employees (Unpublished doctoral dissertation). Management in Organizational Leadership, University of Phoenix.

Laub, J. A. (1999). Assessing the servant organization: Development of the Organizational Leadership Assessment (OLA) instrument (Unpublished doctoral dissertation). Florida Atlantic University, Boca Raton, FL.

Laub, J. (2003). From paternalism to the servant organization: Expanding the Organizational Leadership Assessment (OLA) model.Paper presented at the 2003 meeting of the Servant Leadership Roundtable, Virginia Beach, VA.

Liden, R. C., \& Maslyn, J. M., (1998). Multidimensionality of leader-member exchange: An empirical assessment through scale development. Journal of Management, 24(1), 43-72.

Locke, E. A. (1976). The nature and causes of job satisfaction inside. In M. D. Dunnette (Eds.), Handbook of industrial and organizational psychology (pp. 1297-1349). Chicago, IL: Rand McNally.

Luthans, F. (2002). The need for and meaning of positive organizational behavior. Journal of Organizational Behavior, 23, $695-706$.

Madlock, P. E. (2008). The link between leadership style, communicator competence and employee satisfaction. Journal of Business Communication, 45(1), 61-78.

Mayer, D. M., Bardes, M., \& Piccolo, R. F. (2008). Do servant leaders help satisfy follower needs? An organizational justice perspective. European Journal of Work \& Organizational Psychology, 17(2), 180-187.

Oner, Z. H. (2012). Servant leadership and paternalistic leadership styles in the turkish business context: A comparative empirical study. Leadership \& Organization Development Journal, 33(3), 300-316.

Ozutku, H. (2007). Yönetici-ast etkileşimiile iş tatmini arasındaki ilişki. Amme İdaresi Dergisi,40(2), Haziran, 79-98.

Page, D., \& Wong, P. T. P. (2000). A conceptual framework for measuring servant leadership. In S. Adjibolooso (Ed.), The human factor in shaping the course of history and development (pp. 69-110). Lanham, MD: University Press of America.

Patterson, K. (2003). Servant leadership: A theoretical model (Doctoral dissertation). The School of Leadership Studies, Regent University.

Reinke, S. J. (2004). Service before self: Towards a theory of servant-leadership. Global Virtue Ethics Review, 3, 30-57.

Russell, R. F., \& Stone, A. G. (2002). A review of servant leadership attributes: Developing a practical model. Leadership \& Organization Development Journal, 23(3), 145-157. 
Spears, L. (1995). Introduction: Servant-leadership and Greenleaf legacy. In L. Spears (Eds.), Reflections on leadership. How Robert K. Greenleaf's theory of servant leadership influenced today's top management thinkers (pp. 1-14). New York, NY: John Wiley \& Sons.

Spears, Lary C. (2010). Character and servant leadership: Ten characteristics of effective, caring leaders. The Journal of Virtues \& Leadership, 1(1), 25-30.

Stone, A. G., Russell, R. F., \& Patterson, K., (2004). Transformational versus servant leadership: A difference in leader focus. The Leadership \& Organization Development Journal, 25(4), 349-361.

Van Dierendonck, D. (2011). Servant leadership: A review and synthesis. Journal of Management, 37(4), 1228-1261.

Van Dierendonck, D., \&Nuijten, I. (2011). The servant survey (SLS): Development and validation of a multidimensional measure. Journal of Business Psychology, 26(3), 249-267.

Washington, R. R. (2007). Empirical relationships among servant, transformational and transactional leaders: Similarities, differences, and correlations with job satisfaction and organizational commitment (Unpublished doctoral dissertation). Graduate Faculty of Auburn University, Alabama.

Weiss, D. J., Dawis, R. V., England, G. W., \& Lofquist, L. H. (1967). Manual for the Minnesota satisfaction questionnaire. Vol 22, Minnesota Studies in Vocational Rehabilitation, Minneapolis: University of Minnesota, Industrial Relations Center.

Winston, B. E., \& Ryan, B. (2008). Servant leadership as a humane orientation: Using the GLOBE study construct of humane orientation to show that servant leadership is more global than western. International Journal of Leadership Studies, 3(2), $212-222$.

Wu, L. Z., Tse, E. C. Y., Fu, P., Kwan, H. K., \& Liu, J. (2013). The impact of servant leadership on hotel employees' "servant behavior”. Cornell Hospitality Quarterly, 54(4), 383-395. 